\title{
The Impact of Outbound Training Activity on Organization Mission Statement (Case in Education Mission Statement MMT-ITS)
}

\author{
Gogor Arif Handiwibowo ${ }^{1}$, Mokhamad Suef ${ }^{2}$
}

\begin{abstract}
In the review of organizational behavior, effective organizations require process variables component. One of the process variables form is the existence of training design for members of the organization. The training can encourage an organization member to be an effective member. Outbound training as one of the training methods has been popular since the 1990s and has become a trend for human resource development. As a training method, outbound training with several specific goals has been widely researched and has proven to have a positive impact on team building in teamwork. On the other hand, an organization has formulated an organizational vision in the strategic management context. The organization vision than set the mission statements to coordinate of proposed goals of the organization. Furthermore, every activity in an organization should reflect and base on mission statements value to achieve its strategic competitiveness. This research examines the role of outbound training objective as a contingency factor which affects the mission statement of an organization. The research took the case in MMT-ITS as the education organization. The outbound training objective divide into two objectives, the scientific objective, and internal objective and set as the variable factor. The mission statement studied in this case is education mission statement in MMT-ITS.
\end{abstract}

Keywords — Organizational behavior, outbound training objective, mission statement, strategic management, MMT-ITS.

\section{INTRODUCTION}

$\mathbf{I}_{\mathrm{c}}^{\mathrm{n}}$ the review of Organizational Behavior, a key component of an effective organization can be incorporated into four categories. The components are resources, composition, work design/role and process variables that occur. Especially for process variables, special training can encourage an individual to be a team player, meaning that this individual will play a more important role in the context of the effective organization [1].

Outbound training (sometimes called Adventure-Based Team Development, Team Building Training or Outdoor Training Programs) as one of the training methods, has been popular since the 1990s and has become a trend for human resource development [2]. Several studies have proven the impact of team building training in teamwork across multiple organizational / business backgrounds [3] [4] [5].

In the context of education, outbound training is also implemented to assist students in learning soft skills, especially in higher education. Some studies conclude good learning outcomes for students to absorb the content of team building training values [6] [7] [8] [9].

Since 2005, MMT-ITS has used the method of the outbound training program to its students. One of the learning processes that must be passed by MMT-ITS students is the new students must follow the series of activities Information and Orientation (I/O). The I/O activities are intended to make the new students of MMT-ITS faster to know the organization of ITS in

${ }^{1}$ Gogor Arif Handiwibowo is with Departement of Management of Technology, Institut Teknologi Sepuluh Nopember, Surabaya, 60111, Indonesia. E-mail: banu.affan@yahoo.com.

${ }^{2}$ Mokhamad Suef is with Departement of Industrial Engineering, Institut Teknologi Sepuluh Nopember, Surabaya, 60111, Indonesia. general and MMT-ITS in particular and the learning pattern in MMT-ITS. In the I/O activities, there are sub activities called outbound that are experimental learning. The outbound sub-activities become obligatory for all new students MMT-ITS and become full of students to be able to submit a thesis proposal hearing.

From the angle of organizational perspective, MMTITS has several models of organizational members. There is a board of directors, administration personnel, lecturers and students. Organizations can be called effective when each member can synergize with the indication of collective performance, positive synergy, individual accountability \& mutual and complementary distribution capability [1]. Similarly, the MMT-ITS organization is also required to be an effective organization.

On the other hand, MMT-ITS as one of the organs in the big organization of Institut Teknologi Sepuluh Nopember (ITS) has the vision of its organization to be achieved. The vision of the organization is embodied in the organization's mission as a way of achieving that vision. The mission set forth within the MMT-ITS organization is a reference scale that must be pursued continuously to achieve. By evaluating the achievement of this organization's mission statement can be seen how the achievement of the organization (in this case MMTITS) in reaching its strategic competitiveness [10].

Generally, this paper is based on strategic management review and organizational behavior. The study will analyze the possibility hypothesis correlation between the objectives of an activity related to organizational treatment (in this case is an outbound activity) with an organizational mission that has been predetermined. It is necessary to see the implementation process of the established strategic formulation [11]. 


\section{LITERATURE REVIEW}

\section{A. Outbound Training}

Outbound Training is a fun and challenging outdoor activity. Outbound training activities are implemented with life simulation activities that are applied in educational, creative, attractive, and recreational games. The goal is as a means of self-development and group. Through outbound training, new personalities are expected to be motivated, courageous, confidence, creative thinking, have a sense of togetherness, responsibility, cooperative and mutual trust [7].

Outbound training is one method of learning with experimental learning. The outbound training activity provides some games that have certain rules and goals. Each game in outbound training activities is meaningful, philosophical, and loaded with useful symbolic messages and helps in the process of building character toward success in life, both individual success and team success. The outbound training method is the most effective method of accommodating/demanding needs for a training outcome. This method is effective in building an understanding of a concept and building the behavior of individual characters [9].

In the organizational point of view, in carrying out its activities, organizational managers will design and arrange a series of activities. While a certain activity within the scope of the organization must have certain objectives that have been planned previously. Outbound training as one of the activities that exist within the organization also has a series of specific goals. The scientific literature describes some of the objectives of outbound training activity is as follows [12]:

1. Effective communication

2. Team building

3. Problem-solving

4. Self-confidence

5. Leadership

6. Synergy

7. Fun games

8. Concentration

9. Fairness

In the study, the objectives of outbound training activity in MMT-ITS shows that there are several other objectives to be given to the participants of MMT-ITS outbound training by MMT-ITS manager. The objectives of outbound training are quite specific and desirable to be achieved by participants outbound training MMT-ITS and called objectives internal MMT-ITS. While the additional objectives of internal MMT-ITS obtained from the results of interviews with MMT - ITS board of directors as follows:

1. Awaken the sense of belonging to the campus

2. Awaken the sense of proud to campus

3. Enhance the egalitarian among students

4. Enhance public speaking skill

5. Enhance scientific debate skill

\section{B. Vision and Mission}

Vision is the future view of an organization. Vision is the basic factor that reflects the current situation comprehensively, reinforces the organization's goals and the realization of organizational strategy. Vision is the choice and lifestyle of the organization [13]. A good vision should be able to clearly explain in which direction an organization will move [14].

The organization's mission explains why an organization exists. The mission of an organization is a manifesto that differentiates it from one organization to another, assigns identity and declares to the external environment why the organization is running its activities. The organization's mission helps the organization in finding and utilizing its resources to achieve its goals [15].

In this case study the mission of MMT-ITS organization related to the education field will be analyzed its correlation that is [16]:

1. Provide graduate level program and develop a future-oriented curriculum with high-level and advanced competencies to respond and adapt of change

2. Provide high-quality graduates in the field of Management of Technology

3. Provide graduates with high commitment in the field of Management of Technology

4. Develop an innovative teaching \& learning process by providing educational facilities $\&$ infrastructure and conducive academic atmosphere

\section{RESEARCH FRAMEWORK \& HYPOTHESIS}

As illustrated in the objective of this study that to determine the correlation between the objectives of outbound training activities and organizational mission in MMT-ITS, therefore it can be determined there are three pieces of variables in this study. The first independent variable is the objective of outbound training in a scientifically. The second independent variable is the objective of outbound training MMT-ITS internally. Then the third variable is the organizational mission that is dependent on the two previous independent variables before. The purpose of this research is the developing of research framework as shown in figure 1 .

The correlation between variables will be connected through two hypotheses developed as follows:

1. Hypothesis 1: The objective of Outbound training scientifically has a positive relationship to the Mission Statement of Education in MMT-ITS

2. Hypothesis 2: The objective of Outbound training internally MMT-ITS has a positive relationship to the Mission Statement of Education in MMT-ITS

Where variables and indicators of the research framework shown in table 1 .

\section{METHOD}

\section{A. Samples}

Empirical data were obtained through a random survey to the MMT-ITS students who have attended the outbound training program and have attended the lecturing program in MMT-ITS, so it is assumed to have known and understood the mission of education in MMT-ITS. The survey was conducted from March to April 2017 to students of semesters 2 and 3. Out of a total of 160 questionnaires distributed, 102 questionnaires were returned. Thus approximately $63.8 \%$ of the total questionnaires are distributed into data and can be processed. Of the 102 returned questionnaires, 63 
were questionnaires from $2^{\text {nd }}$-semester students, and 39 questionnaires were from students of the $3^{\text {rd }}$ semester. Table 1.

VARIABLES \& INDICATORS

\begin{tabular}{ll}
\hline \hline Variables & Indicators \\
\hline Scientific (X1) & Effective Communication (X1.1) \\
& Team Building (X1.2) \\
& Problem Solving (X1.3) \\
& Self-confidence (X1.4) \\
& Leadership (X1.5) \\
& Synergy (X1.6) \\
& Fun games (X1. 7) \\
& Concentration (X1.8) \\
& Fairness (X1.9) \\
& Self-Belonging (X2.1) \\
& Campus Proud (X2.1) \\
Internal (X2) & Equality (X2.3) \\
& Public Speaking Skill (X2.4) \\
& Debate Skill (X2.5) \\
& Curriculum (Y1) \\
& Alumni Quality (Y2) \\
Mission (Y1) & Alumni Commitment (Y3) \\
& Education Process (Y4) \\
\hline \hline
\end{tabular}

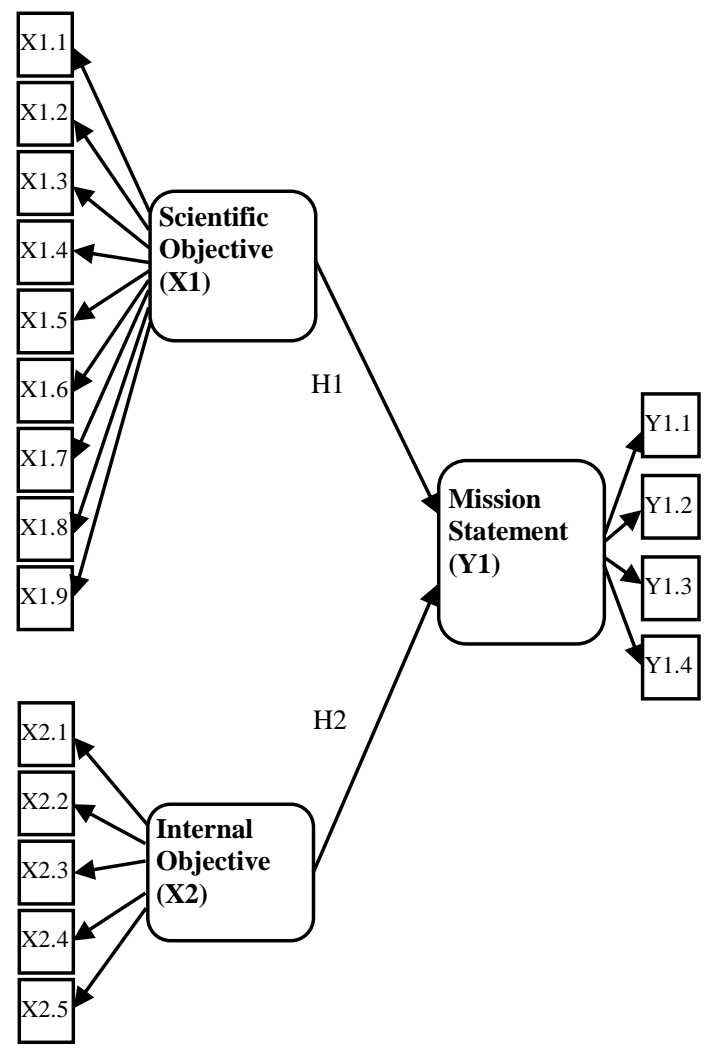

Figure 1. Research Framework.

\section{B. Measure}

The distributed questionnaires were analyzed using the Structural Equation Modeling - Generalized Structural Component Analysis (SEM-GSCA) method where each stage will affect the next stage. There are at least five stages namely [17]:

1. Designing Model Specifications

2. Constructing Path Diagram

3. Define Setting Algorithm \& Mission Value and define Bootstrap Iteration \& Resampling

4. Evaluation of Model Fit Criteria

5. Evaluation of Measurement \& Structural Model

\section{RESULT}

\section{A. Data Analysis}

The reliability analysis was conducted by calculating the Cronbach $\alpha$ for all variables. The reliability analysis refers to the fact that a scale should consistently reflect the construct it is measuring. The SEM-GSCA method by online software GeSCA was employed to examine the data reliability \& validity. Cronbach $\alpha$ for Scientific Objective variable of (Alpha) 0.909. Cronbach $\alpha$ for Internal Objective variable of (Alpha) 0.876. Cronbach $\alpha$ for Mission Statement variable of (Alpha) 0,924. It is found that all variables have Cronbach $\alpha$ more than 0.7. Thus, all the studied variables have been considered reliable because the Cronbach value $\alpha$ is greater than 0.7 [17]. In another word, all of the variables (Scientific Objective variable, Internal Objective variable, and Mission Statement variable) consistently reflect the construct it is measuring.

Meanwhile, to measure the validity of each variable obtained with the size AVE (Average Variance Extracted). The validity analysis is needed to measure the accuracy degree of accuracy of measuring instruments. The recommended AVE is worth more than 0.5. The AVE value for the Scientific Objective variable is 0.593 . While the value of AVE for Internal Objective variable of 0.671 . And the AVE value for the Mission Statement variable is 0.820 . With each AVE value among the variables greater than 0.5 then the research variable is valid [17]. In the other word, all of the variables (Scientific Objective variable, Internal Objective variable, and Mission Statement variable) are accurate to measuring its instruments.

The results of variable validity and reliability tests are reported in Table 2 .

TABLE 2 .

MEASUREMENT MODEL

\begin{tabular}{llllll}
\hline \hline Variable & Loading & & Weight & \multicolumn{2}{l}{ SMC } \\
\hline Estimate SE & CR & Estimate SE & CR & $\begin{array}{l}\text { Estima } \\
\text { te }\end{array}$ & SE CR \\
\hline
\end{tabular}

\begin{tabular}{lllllll}
\hline Scientific AVE $=0.593$, Alpha $=0.909$ \\
\hline$X 1.1 \quad 0.835$ & $0.04319 .64^{*} 0.174$ & 0.020 & $8.86^{*}$ & 0.698 & 0.06910 .13
\end{tabular}

$\begin{array}{llllllll}X .1 .2 & 0.802 & 0.055 & 14.54^{*} 0.143 & 0.017 & 8.53^{*} & 0.643 & 0.0877 .43^{*}\end{array}$

$\begin{array}{llllllll}\mathrm{X} .1 .3 & 0.748 & 0.0809 .39^{*} & 0.150 & 0.012 & 12.47^{*} 0.560 & 0.1134 .94^{*}\end{array}$

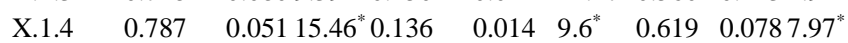

$\begin{array}{llllllll}X .1 .5 & 0.891 & 0.03624 .61^{*} 0.174 & 0.020 & 8.56^{*} & 0.794 & 0.063 & 12.69^{*}\end{array}$

$\begin{array}{llllllll}\mathrm{X} .1 .6 & 0.771 & 0.05713 .57^{*} 0.134 & 0.012 & 11.19^{*} 0.594 & 0.0866 .93^{*}\end{array}$

$\begin{array}{llllllll}\mathrm{X} .1 .7 & 0.609 & 0.0728 .41^{*} & 0.113 & 0.013 & 8.57^{*} & 0.371 & 0.0854 .33^{*}\end{array}$

$\begin{array}{lllllllll}X .1 .8 & 0.639 & 0.0778 .28^{*} & 0.107 & 0.014 & 7.67^{*} & 0.408 & 0.0994 .12^{*}\end{array}$

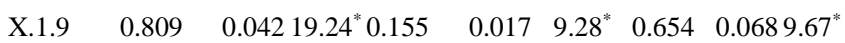

Internal $\mathrm{AVE}=0.671$, Alpha $=0.876$

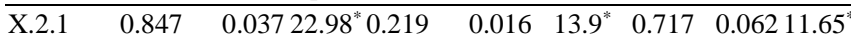

$\begin{array}{lllllll}X .2 .2 & 0.868 & 0.04021 .66^{*} 0.291 & 0.025 & 11.59^{*} 0.754 & 0.069 & 10.94^{*}\end{array}$

$\begin{array}{lllllll}\mathrm{X} .2 .3 & 0.816 & 0.042 & 19.44^{*} 0.245 & 0.015 & 16.03^{*} 0.666 & 0.0689 .79^{*}\end{array}$

$\begin{array}{lllllll}\mathrm{X} .2 .4 & 0.812 & 0.04518 .11^{*} 0.246 & 0.017 & 14.59^{*} 0.660 & 0.0729 .22^{*}\end{array}$

$\begin{array}{lllllll}X .2 .5 & 0.748 & 0.061 & 12.28^{*} 0.216 & 0.016 & 13.85^{*} 0.560 & 0.0896 .32^{*}\end{array}$

Mission $\mathrm{AVE}=0.820$, Alpha $=0.924$

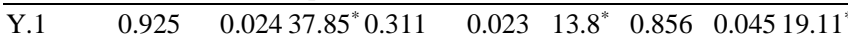

$\begin{array}{lllllll}Y .2 & 0.915 & 0.03129 .36^{*} 0.256 & 0.021 & 12.18^{*} 0.838 & 0.05614 .93^{*}\end{array}$

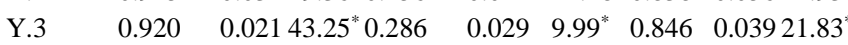

\begin{tabular}{lllllll}
$\mathrm{Y} .4$ & 0.861 & 0.052 & $16.44^{*} 0.249$ & 0.018 & $14.21^{*} 0.741$ & $0.0868 .62^{*}$ \\
\hline \hline
\end{tabular}

$\mathrm{CR}^{*}=$ significant at .05 level

The SEM-GSCA method was employed to examine the Goodness of Fit. The evaluation of the fit model is done on the data. The goodness of Fit Model Structural obtained with FIT Value size accepted if value $\geq 0,5$. 
The FIT of the model was obtained at 0.604 , so it can be concluded that the structural model analyzed can explain the phenomenon being studied [18]. The goodness of Fit Overall Model is obtained by GFI (Goodness of Fit Index) and SRMR (Standardized Root Mean Square Residual). GFI on the model showing the value of 0.980 and SRMR shows the value of 0.064 . The recommended GFI value is $>0.9$ and the SRMR value is $<0.08$ [18]. So with the value of GFI model $0.980>0.90$ and SRMR value model $0.064<0.08$ then the model is considered to be appropriate.

The results of Goodness of Fit tests are reported in Table 3.

\begin{tabular}{cc}
\multicolumn{2}{c}{ TABLE 3. MODEL FiT } \\
\hline \hline FIT & 0.604 \\
GFI & 0.980 \\
SRMR & 0.064 \\
\hline \hline
\end{tabular}

TABLE 4.

SCIENTIFIC VARIABLE MEASUREMENT

\begin{tabular}{|c|c|c|c|c|c|c|c|c|c|}
\hline \multirow[t]{2}{*}{ Variable } & \multicolumn{3}{|c|}{ Loading } & \multicolumn{3}{|l|}{ Weight } & \multicolumn{3}{|l|}{ SMC } \\
\hline & \multicolumn{2}{|c|}{ Estimate SE } & CR & \multicolumn{2}{|c|}{ Estimate SE } & $\mathrm{CR}$ & \multicolumn{2}{|c|}{ Estimate SE } & CR \\
\hline \multicolumn{10}{|c|}{ Scientific AVE $=0.593$, Alpha $=0.909$} \\
\hline X.1.1 & 0.835 & \multicolumn{3}{|c|}{$0.04319 .64 * 0.174$} & \multicolumn{2}{|c|}{$0.0208 .86^{*}$} & 0.698 & \multicolumn{2}{|c|}{0.06910 .13} \\
\hline $\mathrm{X} .1 .2$ & 0.802 & \multicolumn{3}{|c|}{$0.05514 .54^{*} 0.143$} & \multicolumn{2}{|c|}{$0.0178 .53^{*}$} & 0.643 & \multicolumn{2}{|c|}{$0.0877 .43^{*}$} \\
\hline X.1.3 & 0.748 & \multicolumn{2}{|c|}{0.0809 .39} & 0.150 & \multicolumn{2}{|c|}{$0.01212 .47^{*}$} & $* 0.560$ & \multicolumn{2}{|c|}{$0.1134 .94^{*}$} \\
\hline X.1.4 & 0.787 & \multicolumn{3}{|c|}{$0.05115 .46^{*} 0.136$} & \multicolumn{2}{|c|}{$0.0149 .6^{*}$} & 0.619 & \multicolumn{2}{|c|}{$0.0787 .97^{*}$} \\
\hline X.1.5 & 0.891 & \multicolumn{3}{|c|}{$0.03624 .61^{*} 0.174$} & \multicolumn{2}{|c|}{$0.0208 .56^{*}$} & 0.794 & \multicolumn{2}{|c|}{0.06312 .69} \\
\hline X.1.6 & 0.771 & \multicolumn{3}{|c|}{$0.05713 .57^{*} 0.134$} & \multicolumn{2}{|c|}{0.01211 .19} & $* 0.594$ & \multicolumn{2}{|c|}{$0.0866 .93^{*}$} \\
\hline X.1.7 & 0.609 & \multicolumn{2}{|c|}{$0.0728 .41^{*}$} & 0.113 & \multicolumn{2}{|c|}{$0.0138 .57^{*}$} & 0.371 & \multicolumn{2}{|c|}{$0.0854 .33^{*}$} \\
\hline X.1.8 & 0.639 & \multicolumn{2}{|c|}{$0.0778 .28^{*}$} & 0.107 & \multicolumn{2}{|c|}{$0.0147 .67^{*}$} & 0.408 & \multicolumn{2}{|c|}{$0.0994 .12^{*}$} \\
\hline X.1.9 & 0.809 & \multicolumn{3}{|c|}{$0.04219 .24^{*} 0.155$} & \multicolumn{2}{|c|}{$0.0179 .28^{*}$} & 0.654 & \multicolumn{2}{|c|}{$0.0689 .67^{*}$} \\
\hline
\end{tabular}

B. Latent Variable Analysis

1) Variable Scientific Objective

In Scientific Objective variables nine indicators affect the formation of Scientific Objective variable value. If we look at the result of measurement of estimate weight obtained from each indicator, we get the indicator of Effective Communication (X.1.1), and an indicator of Leadership (X.1.5) is the highest value among others. The value of the estimated indicator is the largest among the other indicators of 0.174 . But generally, the nine indicators in Scientific Objective Variable show almost the same impact. It is shown that Team Building (X.1.2), Problem Solving (X.1.3), Self-confidence (X.1.4), Synergy (X.1.6), Fun Games (X.1.7), Concentration (X.1.8) and Fairness (X.1.9) indicators have similar weight estimation value with the Effective Communication and Leadership. The Concentration indicator which has the lowest weight estimation value (0.107) only has a gap of 0.057 with Effective Communication and Leadership. This indicates that the indicator Effective Communication and Leadership cannot be an indicator that the ablest to describe Scientific Objective variable because it has an insignificant weight estimation with other indicators.

Based on the critical point value obtained, Effective Communication and Leadership provide a highest significant influence on Scientific Objective variables. The critical point obtained Effective Communication indicator is $8.86^{*}$ and Leadership indicator is equal to $8.56^{*}$ which is significant at $95 \%$ reliability level.
The result of GeSCA measurement of Scientific Objective variable shown in Table 4.

\section{2) Variable Internal Objective}

In the Internal Objective variable, five indicators affect the formation of the value of Internal Objective variable. If we look at the results of the measurement of the estimated weight obtained from each indicator, the Proud Campus indicator is the highest value among others. The value of the estimated indicator is the largest among the other indicators of 0.291. But generally, the five indicators in Internal Objective Variable show almost the same impact. It is shown that Self-Belonging (X.2.1), Equality (X.2.3), Public Speaking Skill (X.2.4) and Debate Skill (X.2.5) indicators have similar weight estimation value with the Campus Proud. The Debate Skill indicator which has the lowest weight estimation value (0.216) only has a gap of 0.075 with Proud Campus indicator. This indicates that the indicator Campus Proud cannot be an indicator that the ablest to describe Internal Objective variable because it has an insignificant weight estimation with other indicators.

Based on the critical point value obtained, campus proud gives a highest significant influence on Internal Objective variables. The critical point obtained by campus proud is $11.59 *$ which is significant at the $95 \%$ reliability level.

The result of GeSCA measurement of Internal Objective variable shown in Table 5.

TABLE 5.

INTERNAL VARIABLE MEASUREMENT

\begin{tabular}{|c|c|c|c|c|c|c|c|c|}
\hline \multirow[t]{2}{*}{ Variable } & \multicolumn{2}{|l|}{ Loading } & \multicolumn{3}{|l|}{ Weight } & \multicolumn{3}{|l|}{ SMC } \\
\hline & Estimate $\mathrm{S}$ & $\mathrm{CR}$ & Estimat & e SE & CR & Estima & e SE & CR \\
\hline Internal & \multicolumn{8}{|c|}{$\mathrm{AVE}=0.671$, Alpha $=0.876$} \\
\hline X.2.1 & $0.847 \quad 0$. & \multicolumn{2}{|c|}{$0.03722 .98^{*} 0.219$} & \multicolumn{2}{|c|}{$0.01613 .9^{*}$} & 0.717 & \multicolumn{2}{|c|}{$0.06211 .65^{*}$} \\
\hline X.2.2 & 0.868 & \multicolumn{2}{|c|}{$0.04021 .66^{*} 0.291$} & \multicolumn{3}{|c|}{$0.02511 .59 * 0.754$} & \multicolumn{2}{|c|}{$0.06910 .94^{*}$} \\
\hline $\mathrm{X} .2 .3$ & 0.816 & \multicolumn{2}{|c|}{$0.04219 .44^{*} 0.245$} & \multicolumn{3}{|c|}{$0.01516 .03^{*} 0.666$} & \multicolumn{2}{|c|}{$0.0689 .79^{*}$} \\
\hline X.2.4 & 0.812 & \multicolumn{2}{|c|}{$0.04518 .11^{*} 0.246$} & \multicolumn{3}{|c|}{$0.01714 .59^{*} 0.660$} & \multicolumn{2}{|c|}{$0.0729 .22^{*}$} \\
\hline $\mathrm{X} .2 .5$ & 0.748 & \multicolumn{2}{|c|}{$0.06112 .28^{*} 0.216$} & \multicolumn{2}{|c|}{0.01613 .85} & $5^{*} 0.560$ & \multicolumn{2}{|c|}{$0.0896 .32^{*}$} \\
\hline
\end{tabular}

\section{3) Variable Mission Statement}

In Mission Statement variables four indicators affect the formation of Mission Statement variable value. If we look at the result of the measurement of estimate weight obtained from each indicator, we get the indicator Curriculum (Y.1) is the highest value among others. The value of the estimated indicator is the largest among the other indicators that amounted to 0.311. But generally, the four indicators in Mission Statement Variable show almost the same impact. It is shown that Alumni Quality (Y.2), Alumni Commitment (Y.3) and Education Process (Y.4) indicators have similar weight estimation value with the Curriculum. The Education Process indicator which has the lowest weight estimation value (0.249) only has a gap of 0.062 with Curriculum indicator. These indicate that the Curriculum indicator cannot be an indicator that the ablest to describe Internal variable because it has an insignificant weight estimation with other indicators.

Based on the critical point value obtained, the curriculum has a highest significant influence on the variable Mission Statement. The critical point obtained by curriculum is $13.8 *$ which is significant at the $95 \%$ reliability level. 
The result of GeSCA measurement of Mission Statement Variables shown in Table 6: TABLE 6.

Mission Statement VARIABLE MEASUREMENT

\begin{tabular}{|c|c|c|c|c|c|c|c|c|}
\hline \multirow[t]{2}{*}{ Variable } & \multicolumn{2}{|l|}{ Loading } & \multicolumn{3}{|l|}{ Weight } & \multicolumn{3}{|l|}{ SMC } \\
\hline & Estimate SE & $\mathrm{CR}$ & Estimat & & CR & Estime & & CR \\
\hline Mission & \multicolumn{8}{|c|}{$\mathrm{AVE}=0.820$, Alpha $=0.924$} \\
\hline Y.1 & $\begin{array}{ll}0.925 & 0.1\end{array}$ & \multicolumn{2}{|c|}{$0.02437 .85 * 0.311$} & \multicolumn{2}{|c|}{$0.02313 .8^{*}$} & 0.856 & \multicolumn{2}{|c|}{$0.04519 .11^{*}$} \\
\hline Y.2 & 0.915 & \multicolumn{2}{|c|}{$0.03129 .36^{*} 0.256$} & \multicolumn{2}{|c|}{0.02112 .18} & ${ }^{*} 0.838$ & \multicolumn{2}{|c|}{$0.05614 .93^{*}$} \\
\hline Y.3 & 0.920 & \multicolumn{2}{|c|}{$0.02143 .25^{*} 0.286$} & \multicolumn{2}{|c|}{$0.0299 .99^{*}$} & 0.846 & \multicolumn{2}{|c|}{$0.03921 .83^{*}$} \\
\hline Y.4 & 0.861 & \multicolumn{2}{|c|}{$0.05216 .44^{*} 0.249$} & \multicolumn{2}{|c|}{0.01814 .21} & ${ }^{*} 0.741$ & \multicolumn{2}{|c|}{$0.0868 .62^{*}$} \\
\hline
\end{tabular}

\section{Relationship Model Testing \& Discussion}

The SEM-GSCA method by online software GeSCA was employed to examine the relationship. The path coefficients of the variables can identify the relationship of the variables. The positive and significant relationship when CR value of each relationship > 1.96 with $95 \%$ confidence level. The scientific Objective variable has a positive and significant relationship with Mission Statement variable because it has CR value of 4.36 and > 1.96 for $95 \%$ reliability level so that outbound objectives scientifically affect the achievement of organizational Mission Statement. Thus it can be concluded that Hypothesis 1 is accepted.

The Objective internal variable has a positive and significant relationship with Mission Statement variable because it has CR value of 2.96 and > 1.96 for $95 \%$ reliability level so that outbound objectives internally affect the achievement of organizational Mission Statement. Thus it can be concluded that Hypothesis 2 is accepted.

When viewed by the value of the estimated path of each variable, the Scientific Objective variable has an estimate path value of 0.549 which is higher than the value of the estimated path of the Internal Objective variable of 0.342 . Thus, the Scientific Objective variable is more influential in increasing the value of the Mission Statement variable because it has a higher estimate path value than the Internal Objective variable.

The result of GeSCA measurement of Path coefficients shown in Table 7.

TABLE 7.

PATH COEFFICIENTS

\begin{tabular}{|c|c|c|c|}
\hline \multicolumn{4}{|l|}{ Path Coefficients } \\
\hline & Estimate & SE & $\mathbf{C R}$ \\
\hline Scientific->Mission & 0.549 & 0.126 & $4.36^{*}$ \\
\hline Internal-> Mission & 0.342 & 0.116 & $2.96^{*}$ \\
\hline
\end{tabular}

$\mathrm{CR}^{*}=$ significant at .05 level

Path analysis result from GeSCA shown in figure 2.

\section{CONCLUSION}

The study has examined the relationship between Outbound Objective and Mission Statement of an organization. There are two kinds of outbound objective, as scientific objective and internal organization objective. Two hypotheses was supported by the empirical data in which there were significant relationships between scientific objective and mission statement and between internal objective and mission statement. But as quantitatively, the scientific objective was a higher relationship to the mission statement compared to the internal objective.

In a scientific objective, the communication effective and leadership were the main indicators compared to the other indicators. In an internal objective, the campus proud was the main indicator compared to the other indicators. In the mission statement, the curriculum was the main indicator compared to the other indicators.

In this study also shows the absence of dominant factors among the indicators that exist within each variable. Thus, each indicator in a variable has an almost equal degree of contribution to its variable. Our future work would be to extend the study by considering dominant factors among indicators. The extension would provide more information on how outbound objective is related to mission Statement of an organization.

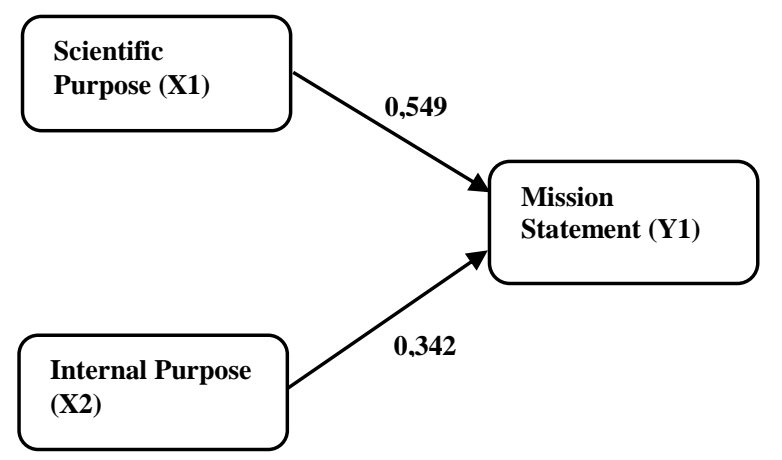

\section{REFERENCES}

[1] Robbins, S.P. (2009) Organizational Behavior. 13th Edition. New Jersey: Prentice Hall Pearson Educational International.

[2] Wagner, R.J., Baldwin, T.T., \& Roland, C. (1991). Outdoor Training: Revolution or Fad? Training \& Development Journal, 45(3), 50-57.

[3] Buchori, S. (2011). "Pelatihan Pembentukan Tim Untuk Meningkatkan Kohesivitas Tim pada Kopertis V Yogyakarta," Jurnal Psikologi, Vol. 38 No. 1, pp. 40 - 51.

[4] Cahyadi, A. (2012), Intervensi Team Building Training Untuk Meningkatkan Kepercayaan terhadap Rekan Kerja dan Kualitas Teamwork di PT. S, Master Thesis, Universitas Indonesia.

[5] Setianingtyas, A.F. (2013). Pengaruh Pelatihan Team Building Untuk Meningkatkan Kohesivitas Tim Kerja di Inna Garuda Yogyakarta, Naskah Publikasi Master Thesis, Universitas Ahmad Dahlan Yogyakarta

[6] Arifin, Z. (2012). Tren dan Inovasi Dalam Pendidikan Manajemen dan Bisnis di Program MM UII Yogyakarta, Proceeding Seminar Nasional APMMI, MK-2-1.

[7] Falah, N. (2014).'Efektifitas Outbound sebagai Metode Pembelajaran (Studi pada Outbound Mahasiswa Jurusan BKI Fakultas Dakwah dan Komunikasi UIN Sunan Kalijaga Yogyakarta)", Jurnal Hisbah, Vol. 11, No. 1. Pp. 53 - 74.

[8] Marimuthu, K.N. \& Mukherjee, S. (2014). Impact of Out-Bound Training (OBT) on MBA Students in Developing Their Leadership Skill: A Study on South India, International Journal of Innovative Research \& Development, Vol. 3 Issue 12, pp. 384-391.

[9] Buchori, S., Ibrahim, M., dan Saman, A. (2016). "Pengaruh Character Education Training meals Outbound Training Untuk Peningkatan Kejujuran dan Integritas," Jurnal Psicologi Pendidikan \& Konseling, Vol. 2 No. 1, pp. $12-19$.

[10] Handiwibowo, G. A. (2016). Evaluasi Strategi Pada Mis Penunjang Proses Belajar Mengajar Yang Inovatif Pada Prasarana Di MMT-ITS Dengan Pendekatan ImportancePerformance Analysis (IPA). In Seminar Nasional Manajemen Teknologi (Vol. 24, No. MMT - ITS, pp. A-1). MMT - ITS. 
[11] David, Fred R. (2013). Strategic Management: Concept and Cases, $14^{\text {th }}$ edition, Pearson, Essex.

[12] Mulyono \& Asti, B. M. (2008). "Smart games for Outbound Training." Yogyakarta: Diva Press.

[13] Dinçer, Ömer. (2006). Stratejik yönetim ve let me politikasi, Sekizinci Basim, Istanbul, Alfa Yayim Daytime.

[14] Thompson, A.A. Jr., and Strickland III A.J. (1999). Strategic Management; Concepts and Cases, Irwin Mc Graw Hill, 11th Edition.

[15] Eren, Erol. (2005). Stratejik yönetim ve let me politikasi. 7. Baski, Istanbul: Beta Basim Yayim Daytime.
[16] Prodi MMT-ITS (2015). Pedoman Akademik MMT-ITS Surabaya.

[17] Latan, H. (2014). Teori, Konsep dan Aplikasi menggunakan GeSCA, Satu Nusa, Bandung

[18] Solimun (2012). Pemodelan Persamaan Structural Generalized Structured Component Analysis (GSCA), Program Studi Statistika, Jurusan Matematika FMIPA Universitas Brawijaya, Malang. 